\title{
Effect of some parameters on the drying-off - 1st oestrus interval Results from 1975-1982
}

\author{
Françoise MARTINAT-BOTTE *, Brigitte BADOUARD *, M. TERQUI ** \\ *I.T.P., 149, rue de Bercy, 75595 Paris Cedex 12 \\ **I.N.R.A., Station de Physiologie de la Reproduction, Nouzilly, 37380 Monnaie
}

France

The effect of some parameters on the onset of oestrus after the end of lactation was studied on the basis of data from the National computerized programme for management of sow herds. The data analysis was performed on two samples (I, $\mathrm{n}: 5867$; II, $\mathrm{n}: 36$ 926) and over two periods at 7-year interval (1975-1982). Synchronization of oestruses between Day 3 and 9 after drying-off represented 85.5 p. 100 as compared to the 1975 value (80 p. 100). Whatever the year, the maximum frequency of oestrus onset was observed on Day 5. The frequency was about 6 p. 100 higher in 1982. Primiparous sows returned to oestrus later than multiparous sows (p. 100 oestrus Day 3 to 9 - primiparous, 1975 : 69.9 p. $100 ; 1982$ : 75.9 p. 100 - multiparous, $1975: 83.5$ p. $100 ; 1982$ : 88.8 p. 100). The optimum synchronization of heats after drying-off (Day 3-9) corresponded to weanings between Day 26 and 35 in primiparous as well as in multiparous sows whatever the year. There was an influence of the season on the return to oestrus. However, in 1982, the «season » effect was more marked in primiparous sows : the variation range between the most favourable months (November to February) and the less favourable ones (Jufy and August) reached 8 p. 100 . It was only 3 p. 100 in multiparous sows. The data analysis per herd $(n=292)$ showed that in $84.2 \mathrm{p}$. 100 of the cases the return to oestrus of the primiparous sows was less synchronized than that of the multiparous ones and this disturbed the batch management.

\section{IV. - REPRODUCTION}

\section{Combination of a progestogen treatment (RU 2267) with different herd management systems for a better control of sow reproduction}

\author{
Françoise MARTINAT-BOTTE *, F. BARITEAU **, J. BUSSIERE **, \\ A. IOBARD $* * *$, M. TERQUI $* *$ \\ *I.T.P., 149, rue de Bercy, 75595 Paris Cedex 12 \\ ** I.N.R.A., Station de Physiologie de la Reproduction, Nouzilly, 37380 Monnaie \\ :*: Roussel-Uclaf, Département des Recherches vétérinaires, \\ 102 et 110 , route de Noisy, 92330 Romainville
}

France

Use of a progestogen treatment (Regumate in oil solution) to control ovulation was tested over a period of one year in nulliparous and multiparous sows subjected to different herd management conditions.

A total of 621 nulliparous, presumably pubertal sows, were administered orally $20 \mathrm{mg}$ Regumate daily for 18 days. At the end of the treatment, half the batch (I) was systematically inseminated on days 6 and 7, the remainder (II) was inseminated after oestrus detection 